\title{
KONTRIBUSI MEDIA SIBER TERHADAP KEBERADAAN SASTRA RELIGI DI MEDIA SOSIAL INSTAGRAM
}

\author{
Raudhatul Jannah ${ }^{1}$ dan Rianna Wati ${ }^{2}$ \\ Universitas Sebelas Maret Surakarta ${ }^{1,2}$ \\ Surel: raudhatul.jannah@student.uns.ac.id ${ }^{1}$ \\ riannawati@staff.uns.ac.id ${ }^{2}$
}

\begin{abstract}
Abstrak
Sastra siber adalah fenomena yang hadir dalam khazanah sastra Indonesia sejak tahun 1990-an. Hadirnya sastra siber membuat banyak genre sastra ikut masuk dan memanfaatkan media siber sebagai tempat menyebarkan karya sastra. Sastra religi sebagai sastra yang dekat dengan masyarakat Indonesia juga ikut masuk ke dalam arus media siber. Instagram adalah salah satu media siber yang digunakan sebagai media penyebaran sastra religi. Terdapat banyak akun sastra religi yang menjadikan Instagram sebagai tempat membagikan karya mereka. Tak dapat dipungkiri media siber memberikan banyak kontribusi terhadap lestarinya sastra religi di tengah masyarakat. Penelitian ini menggunakan pendekatan kualitatif dengan metode deskriptif. Data dalam penelitian ini adalah postingan dalam akun-akun sastra religi yang terdapat di media sosial Instagram, berupa gambar, video, dan kalimat yang digunakan. Hasil penelitian menunjukkan bahwa media siber berkontribusi banyak dalam keberadaan sastra religi di media Instagram. Kontribusi tersebut di antaranya: 1) menjadikan sastra religi sebagai salah satu genre sastra yang bisa dinikmati semua kalangan masyarakat; 2) menyediakan tempat berdakwah tanpa batasan waktu dan tempat; 3) menjadi tempat mencari keuntungan finansial. Selain kontribusi positif, media siber juga membawa dampak negatif seperti tidak adanya filter konten dan meningkatnya risiko plagiarisme.
\end{abstract}

Kata Kunci: Sastra religi, media siber, dan akun.

\section{Jurnal Abstract
Pendahasa, Sastra
Indonesia dan Daerah}

Cyber literature is phenomenon that comes in Indonesian literature around 1990. The presence of cyber literature makes genres in literature join and use cyber media as a platform to spreading literature. Religious literature as one of the genres in literature that close with public also choose one place in cyber media phenomenon. Instagram is one of the cyber media that becomes new platform to spreading religious literature. There is a lot of religious literature account in Instagram and using Instagram as a place to share their works. It can't be denied that cyber media gives a lot of contribution for existence religious literature account in social media like Instagram. This research is qualitative research using descriptive method. Data in this research is religious literature accounts in 
Instagram. The result of this study reveals that cyber media gives contribution to the existence religious literature in Instagram. The contributions are making religious literature as one of the genres that could be enjoy by a lot of people, provide platform to perching without barrier, become place to earn financial gain, but also bring negative effects such as no filter to the contents and increased risk of plagiarism.

Keywords: religious literature, cyber media, and account

\section{PENDAHULUAN}

Perkembangan dunia dan kehidupan manusia selalu disertai dengan perkembangan teknologi. Sejak masa niraksara, kehidupan manusia selalu berkembang mulai dari masa berburu sampai manusia bisa bercocok tanam dan lambat laun tidak lagi hidup nomaden. Saat itu alat-alat bercocok tanam yang terbuat dari batu dianggap sebagai sebuah teknologi. Lalu, ketika tulisan hadir di tengah-tengah kehidupan manusia, tulisan pun dikatakan sebagai teknologi. Plato menganggap tulisan adalah teknologi eksternal. Ong (2013, hlm. 126) menuturkan tulisan dalam makna ketat kata itu, teknologi yang telah membentuk dan memberi daya pada aktivitas intelektual manusia modern, adalah perkembangan yang sangat akhir dalam sejarah manusia. Saat tradisi lisan masih begitu kuat keberadaannya, tulisan hadir dengan semua perubahaan sosial yang di bawanya. Ju Kini, ditemukannya teknologi komputer dan internet memang mengubah sebagian besar cara manusia bertahan hidup. Sebelum internet dan komputer ditemukan, manusia berkomunikasi dengan perantara verbal atau dengan cara saling berkirim surat. Setelah hadirnya internet, manusia tidak perlu lagi menulis surat, menunggu sampai surat itu sampai ke penerima dan harus menunggu lagi untuk mendapatkan balasan. Hanya dengan menekan beberapa tombol pada gawai masingmasing, seseorang sudah bisa terhubung dengan orang lain bahkan di jarak yang jauh sekalipun. Bisa dikatakan, internet merekatkan yang jauh menjadi dekat. Namun tidak dapat dipungkiri jika internet juga membawa dampak buruk lain.

Tidak hanya cara berkomunikasi, munculnya internet juga memberikan napas baru dalam dunia sastra. Hadirnya cyber sastra atau sastra siber adalah salah satu bukti dampak dari internet terhadap dunia sastra. Menurut Endraswara (2013, hlm. 182-183) istilah cyber sastra berasal dari bahasa Inggris yaitu kata cyber, saat kata itu tidak bisa berdiri sendiri. Cyber sendiri memiliki arti 'internet'. Sehingga cyber sastra berarti aktivitas sastra yang memanfaatkan komputer atau internet. Kehadiran sastra siber sendiri memang belum lama di Indonesia. Munculnya sastra internet berkaitan dengan qadirnya internet di Indonesia di kurun waktu 90 tan (Yulhasni, 2018). Sastra siber hadir pada kisaran tahun 1990-an ditandai dengan diterbitkannya buku Antologi Puisi Cyber. Sejak saat itu kemunculan media cyber dalam dunia sastra menjadi semakin masif. Dimulai dari situs dan portal-portal seperti blog, forum-forum yang terdapat di berbagai media sosial seperti Facebook, hingga munculnya berbagai aplikasi baca-tulis seperti Wattpad, Webtoon. Beberapa tahun terakhir bahkan penyebaran 
konten sastra di media sosial seperti Twitter dan Instagram juga semakin marak. Hal itu menunjukkan betapa media siber begitu luas dan bisa menjangkau seluruh lapisan masyarakat terbukti dari menjamurnya kontenkonten sastra di media siber.

Salah satu yang tidak bisa terhindarkan dari pengaruh hadirnya media siber adalah sastra religi. Sastra religi bukan hal asing lagi bagi masyarakat Indonesia. Sejak masa kerajaan Hindu Buddha, keberadaan sastra religi sudah eksis di tengahtengah masyarakat Nusantara. Seperti contohnya kitab-kitab seperti Kitab Negarakertagama. Kemudian, seiring berjalannya waktu muncul juga karyakarya puisi sufi seperti karya Hamzah Fansuri. Selanjutnya, pada masa dewasa ini hadirnya novel-novel bernuansa islami seperti novel karya Asma Nadia dan Habiburrahman El Shirazzy. Hal itu menunjukkan kehadiran sastra religi seperti sudah ikut menemani perkembangan masyarakat Indonesia dari waktu ke waktu.

Sebelum membahas sastra religi, ada baiknya diketahui apa itu religius atau religiusitas yang menjadi akar dari sastra religi. Religius atau religiusitas berarti sesuatu yang bersifat keagamaan, yang mengenai kepercayaan, yang bersifat religi. Religi berarti kepercayaan akan adanya kekuatan adikodrati di atas alam semesta, (Soeharso dan Ana Retnonigsih, 20019, hlm. 418). Menurut Atmosuwito (1989, hlm. 123) religi berarti menyerahkan diri, tunduk dan taat. Dari beberapa pengertian tersebut, dapat ditarik sebuah simpulan bahwa yang dimaksud dengan sastra religi ialah sastra yang bernapaskan keagamaan dan kepercayaan manusia terhadap kekuatan adikodrati di atas alam semesta, serta sastra yang menggambarkan perasaan batin seperti berserah diri dan taat pada Tuhan yang dipercayainya. Sebagai negara dengan tingkat diversivitas yang tinggi, sastra religi di Indonesia tentu saja tidak hanya memuat tentang satu kepercayaan. Setidaknya ada enam kepercayaan yang diakui oleh negara yaitu Islam, Katolik, Kristen, Hindu, Buddha, dan Kong hu $\mathrm{Cu}$. Maka setidaknya ada enam jenis kepercayaan yang mempengaruhi sastra religi di masyarakat.

Instagram adalah salah satu media sosial yang sangat digemari oleh masyarakat. Berdasarkan data di Play Store, aplikasi ini telah diunduh sebanyak satu milyar lebih unduhan dengan rating 4.4 dari lima bintang serta lebih dari 110 juta ulasan dari penggunanya, menjadikan aplikasi ini salah satu aplikasi yang paling populer di era digital ini. Angka ini tentu saja belum digabungkan dengan data di App Store dalam perangkat iOS. Aplikasi ini menyediakan fasilitas untuk membagikan foto dan video untuk para penggunanya dengan membubuhi caption pada unggahan. Fasilitas yang disediakan itu tidak serta merta disiasiakan saja oleh penggunaanya. Bukan hanya akun-akun pribadi, akun bisnis dan akun-akun jenis lain juga tidak mau kalah menggunakan Instagram. Para penggiat maupun penikmat sastra tidak mau ketinggalan. Sudah sejak beberapa tahun terakhir mulai muncul akun-akun sastra yang membagikan karya-karya sastra semacam puisi populer, kata-kata indah, serta video-video pembacaan puisi.

Dalam dunia sastra, keberadaan media Instagram juga memberikan kontribusi terhadap keberlangsungan 
sastra religi di masyarakat. Kehadiran media siber di tengah-tengah dunia sastra memang memberikan banyak pengaruh dan kontribusi tersendiri. Media siber menyebabkan semakin beragamnya tujuan seorang penulis atau sebagai pemilik situs sastra dalam menyebarkan karyanya kepada masyarakat. Fungsi dari media siber dalam dunia sastra tak lagi sebagai media penyebaran karya.

Tak dapat dipungkiri jika kehadiran sastra siber memberikan banyak pengaruh dan dampak pada setiap lini kehidupan manusia, termasuk sastra religi yang sudah sejak lama hidup berdampingan dengan masyarakat. Oleh sebabnya, dalam penelitian ini akan dibahas bagaimana kontribusi media siber terhadap sastra religi utamanya dalam hubungannya dengan keberadaan sastra religi di media sosial Instagram. Bagaimanakah kontenkonten yang disajikan oleh akun-akun sastra religi di media sosial Instagram? Seperti apakah kontribusi media siber bagi keberadaan dan keberlangsungan sastra religi di media sosial Instagram?

Untuk menyelesaikan permasalah penelitian tersebut, harus dilihat seperti apa pola yang ada pada akun-akun sastra religi di media sosial. Pola tersebut dapat dilihat pada unggahan konten baik itu berupa video, tulisan! ataupun gambar. Dengan begitu dapat dilihat apakah tujuan pemilik akun membuat konten sastra religi dan untuk apa saja akun itu digunakan. Setelah itu, dapat ditarik kesimpulan dari berbagai pola yang ada di beberapa akun, kontribusi yang diberikan media siber pada keberadaan sastra religi di media sosial Instagram.

\section{METODE}

Penelitian ini adalah penelitian kualitatif yang menggunakan metode deskriptif. Objek material dalam penelitian ini adalah akun remaja.islami, kisahcintamuslimah, siraman.rohani_, filsafat_hindu, dan buddha.dhamma.kehidupan di Instagram yang konten-kontennya berupa sastra religi. Objek formal penelitian adalah fungsi dan kontribusi media siber terhadap akun-akun sastra religi di Instagram yang dilihat melalui unggahan konten baik caption, video grafis, tulisan, ataupun gambar. Data berupa postingan dalam akun remaja.islami, kisahcintamuslimah, siraman.rohani_, filsafat_hindu, buddha.dhamma.kehidupan yang terdapat di media sosial Instagram, berupa gambar, video, dan kalimat yang digunakan. Teknik interpretasi data menggunakan metode deskriptif yang analisis kontribusinya didasarkan pada cara pemilik akun menggunakan media siber tersebut dan manfaat yang dibawa oleh media siber untuk sastra religi yang tercermin lewat akun-akun yang ada.

\section{HASIL DAN PEMBAHASAN}

\section{Konten-Konten dalam Akun Sastra Religi di Media Sosial Instagram}

Aaktivitas membagikan sesuatu kepada khalayak umum adalah hal yang lumrah di era digital seperti ini. Banyak orang berbondong-bondong menghadirkan konten menarik bahkan kontroversial untuk mendapat pengakuan dari masyarakat. Terdapat berbagai macam konten yang tersebar di media sosial. Sastra adalah salah satunya. Sebagai sebuah karya seni bermediumkan bahasa, sastra adalah sesuatu yang sangat dekat dengan 
manusia. Menurut Koentjaraningrat, bahasa adalah satu dari tujuh unsur kebudayaan. Sebagai sesuatu yang sangat dekat dengan benak masyarakat, sedikit banyak, sastra telah menyumbang pengaruh kepada pembacanya. Sastra disebut sebagai salah satu lembaga sosial yang membentuk tingkah laku masyarakat. Tak jarang, sastra digunakan sebagai cara untuk memberikan pengajaran kepada pembacanya. Mengenai hal ini, tentu saja sastra religi bisa termasuk dalam satu dari berbagai macam sastra yang memberikan pengajaran. Seperti yang sudah dijelaskan di pendahuluan, bahwa sastra religi bisa disebut sebagai karya sastra yang menggambarkan hubungan antara seseorang dengan Tuhannya, seseorang dengan alam semesta. Sastra religi juga bisa disebut sebagai sastra yang mengandung ajaran-ajaran agama tertentu.

Sastra religi adalah sastra yang mengangkat atau berhubungan dengan religi atau kepercayaan tertentu. Untuk masyarakat Indonesia sendiri, kepercayaan dan agama adalah hal yang begitu dekat dengan keseharian. Bahkan Pancasila sebagai dasar negara Indonesia dalam sila pertamanya menyebutkan Ketuhanan Yang Maha Esa. Oleh karena itu, kehidupan beragama bukan lagi hal yang asing bagi masyarakat Indonesia. Semenjak kehidupan beragama adalah hal yang lumrah, muncul berbagai bentuk sastra religi yang memperkaya khazanah sastra Indonesia.

Mengenai fungsi dari sastra itu sendiri seperti menurut Sujarwa (2019: 13-16) sastra memiliki tiga fungsi bagi masyarakat yaitu fungsi dulce et utile, fungsi sosial, dan fungsi kultural. Fungsi dulce et utile ialah sastra berfungsi sebagai sesuatu yang menyenangkan dan berguna. Fungsi sosial sendiri menjadikan karya sastra sebagai dokumen sejarah pemikiran manusia. Fungsi kultural yang lebih menempatkan karya sastra sebagai produk budaya. Sebagai sastra yang bernuansa religi dan/atau kepercayaan tertentu, sastra religi menghadirkan nilai-nilai positif bagi penikmat dan pembacanya. Sastra religi yang selama ini dikenal adalah sastra yang memuat ajaran baik dan tuntunan kehidupan yang baik. Sastra religi dimanfaatkan bermacam-macam oleh masyarakat. Sebagai media untuk mengintrospeksi diri sendiri, sebagai cerminan kehidupan yang ideal yang menunjukkan bagaimana seharusnya manusia berhubungan dengan Tuhannya, berhubungan dengan sesamanya, juga berhubungan dengan alam semesta. Sastra religi juga dimanfaatkan sebagai media untuk memberi pengajaran kepada para pembacanya. Sastra religi juga dimanfaatkan oleh penikmatnya sebagai sarana untuk mencari penghiburan diri yang secara tidak langsung juga mendapatkan pengajaran dari muatanmuatan yang terkandung dalam sastra religi itu sendiri.

Hadirnya sastra religi di tengahtengah media sosial bukan rahasia lagi. Ketika dilakukan pencarian pada kolom media mengetikkan kata kunci sastra religi ataupun sastra islami maka akan muncul banyak hasil pencarian. Mulai dari akun dengan jumlah pengikut fantastis sampai akun-akun kurang populer dengan jumlah pengikut ribuan. namun dapat diketahui dari hasil pencarian yang telah dilakukan oleh penulis, akun-akun sastra islami yang paling mendominasi. Hal itu disebabkan karena Indonesia adalah 
negara dengan pemeluk agama islam paling banyak. Tidak mengherankan lagi jika akun sastra religi dengan ideologi sastra islami banyak ditemukan dan lebih mendominasi. Di bawah ini adalah beberapa akun yang ditemukan di media sosial Instagram yang akan dianalisis dalam penelitian ini.

\section{Akun remaja.islami}

Akun ini adalah akun yang cukup populer. Dengan jumlah pengikut sebanyak 2.8 juta akun serta total postingan berjumlah 45 ribu postingan. Seperti nama pengguna dalam akun ini yang mengandung kata remaja, sasaran utama dari akun ini adalah remaja dengan kisaran umur belasan. Dapat dilihat dari postingan-postingan yang ada, tujuan utama dari akun ini adalah untuk memberikan dakwah kepada para pengikutnya. Semenjak sebagian besar pengikutnya adalah pengguna yang berumur kurang dari 25 tahun, maka bahasa yang digunakan dalam akun ini adalah bahasa-bahasa ringan yang cenderung digemari dan mudah menarik perhatian remaja. Selain itu, pengemasan kontennya juga dibuat semenarik mungkin. Di bawah ini adalah beberapa contoh postingan yang terdapat dalam akun remaja islami:
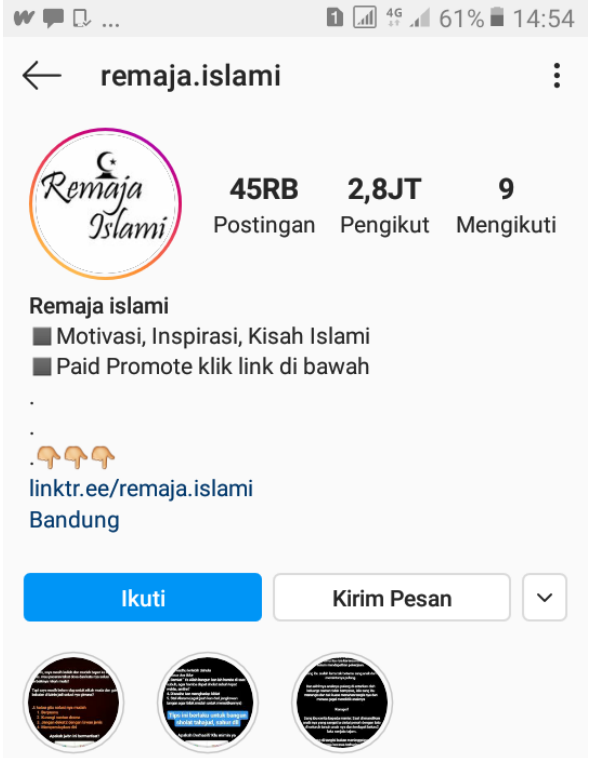

Nikah Muda? tips bangn su... kisah anak ra...

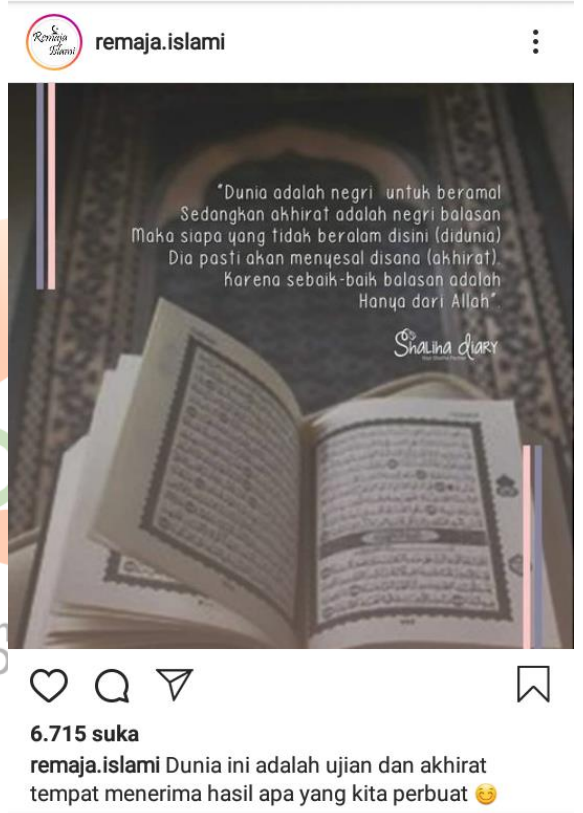

(Gambar 1 dan 2. Tampilan laman Instagram akun remaja.islami)

Konten-konten yang terdapat dalam akun ini terbagi ke dalam beberapa jenis. Konten yang mendominasi ialah konten-konten semacam kata-kata 
bijak, kata-kata mutiara, puisi-puisi pendek. Muatan dalam konten semacam itu ada yang berisi muatan agama Islam, seperti ajakan untuk berserah diri kepada Tuhan, ada juga yang berisi tentang motivasi-motivasi, ajakan untuk berbuat baik. Selain itu, ada juga konten-konten yang berbau romansa seperti membahas topik semacam jodoh dan cinta. Justru, konten-konten semacam inilah yang banyak mendapatkan respons dari para pengikutnya dibandingkan dengan konten yang lain. Akun ini juga banyak mengunggah potongan ayat-ayat Alquran dan hadis semenjak latar belakang religi yang dianut oleh akun ini adalah agama Islam. Hal ini menunjukkan fungsi dakwah Instagram seperti yang sudah tertera di biografi akun memang sudah terlaksana.

Seperti kebanyakan akun-akun dengan jumlah pengikut yang fantastis, kesempatan itu tidak diabaikan begitu saja oleh pengelola akun. Untuk mendapatkan keuntungan dalam segi finansial, banyak postingan yang juga berisi iklan seperti paid promote untuk mendapatkan biaya pasang iklan dari produk yang bekerja sama dengan akun tersebut, sampai konten-konten give away dengan dari berbagai sponsor untuk mendulang jumlah pengikut. Karena seperti sudah rahasia umum, kegiatan give away adalah salah satu jalan pintas mendapatkan banyak pengikut di media sosial dewasa ini. Makin banyak jumlah pengikut dalam satu akun, makin mahal pula biaya pasang iklan yang berlaku di akun tersebut. Hal itu tentu saja memberi keuntungan tersendiri bagi pengelola akun.

Namun meski begitu, sebagian besar konten memang masih sejalan dengan tujuan dari sastra religi yaitu memberikan dakwah dan pengajaran dengan cara yang berbeda. Seperti yang sudah disebutkan sebelumnya, kontenkonten dakwah, inspirasi, dan motivasi hidup masih mendominasi.

Kontribusi media siber dalam keberadan akun remaja.islami adalah memberikan fasilitas media dakwah kepada 2.8 juta pengikutnya. Karena dengan media siber seperti ini yang bisa merealisasikan dakwah kepada 2.8 juta akun dalam satu waktu. Sifat dari internet yang tanpa batas ini pula memungkinkan hal ini dapat terjadi. Selama ini dakwah dikenal sebagai sesuatu yang sedikit membosankan bagi para remaja. Ruang maya sangat digandrungi oleh banyak orang utamanya remaja (Supriani, 2018). Karenanya, dengan kehadiran media siber seperti ini, dakwah kepada kalangan muda bisa dengan mudah dilaksanakan. Dengan balutan bahasa yang ringan dan selipan topik-topik yang digemari namun masih memuat ajaran baik, tentu saja menjadikan akun remaja.islami salah satu rujukan akun sastra religi di media Instagram yang sesuai dengan tujuan sastra religi yaitu memberikan ajaran yang baik pada penikmatnya. Hal ini juga melunturkan pandangan kaku yang menyertai sastra religi. Karena sastra religi adalah sastra icyang kebanyakan ditulis oleh tokohtokohoragama, menjadikan gaya penceritaan atau penuangan ide-ide melalui diksi itu juga mengikuti situasi sosial para pengarang. Menurut Ratna (2009, hlm. 108), karya sastra sebagai manifestasi kelompok atau individu menunjukkan gejala masyarakat, kecenderungan periode tertentu, pandangan dunia, sistem sosial, sebagai bentuk kebudayaan. Hal ini menunjukkan pandangan kaku yang menyertai sastra religi sebelumnya 
hadir karena pandangan dunia pada masa itu. Selain itu, belum adanya fasilitas untuk menyampaikan sastra religi dalam bentuk yang lebih kasual. Kini setelah hadir media siber dengan kebebasannya, pandangan itu mulai luntur dan sastra siber bisa dinikmati oleh siapa pun.

Dengan media siber pula, memungkinkan seseorang bisa mencapai dua hal dalam satu waktu. Pertama memberikan ajaran baik pada orang lain dan yang kedua mendapatkan keuntungan dari kegiatan kapitalis yang dilakukan. Keuntungan yang didapat dari iklan dan lain sebagainya itu sedikit banyak bisa digunakan untuk keberlangsungan akun sastra religi untuk tetap bertahan dan memberikan pengaruhnya di tengahtengah masyarakat.

\section{Akun kisahcintamuslimah}

Akun kisahcintamuslimah memiliki ideologi yan tak jauh berbeda dengan akun yang dibahas sebelumnya. Akun ini memiliki pengikut dengan jumlah 374 ribu akun dan dengan jumlah postingan sebanyak 380 ribu postingan. Konten-konten yang terdapat dalam akun ini bermacam juga jenisnya. Sama seperti kebanyakan akun serupa kontenkontennya berupa pengetahuan seputar Islam, video-video motivasi, cuplikan ceramah, puisi-puisi pendek, nerta video-video grafis pembacaan puisi.

Seperti nama akunnya yaitu kisahcintamuslimah, kebanyakan muatan konten memang membahas soal hal-hal yang berkaitan dengan cinta dan jodoh namun tetap dibalut dengan nuansa religi, seperti contoh:

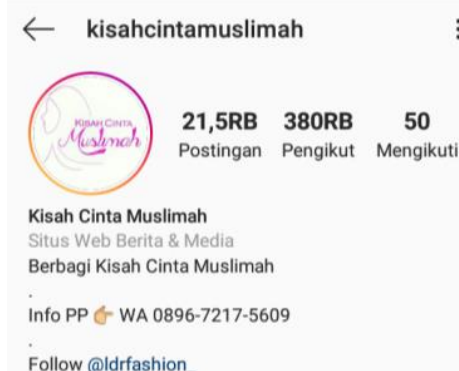

Yuk Belanja Busana Muslim Di Toko Kami $\bullet$ linkinbio.to/kisahcintamuslimah

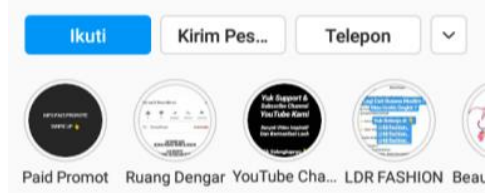

kisahcintamuslimah

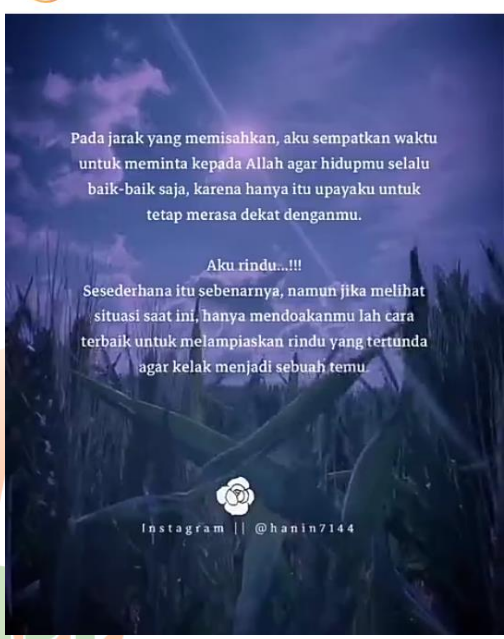

(Gambar 3 dan 4. Tampilan laman Instagram akun kisahcintamuslimah) miah

dan Tidak sohanya itu, terdapat juga konten-konten berisi pengetahuan seputar Islam, potongan ayat Al-Quran, dan hadist. Dengan memanfaatkan jumlah pengikut akun untuk mendapatkan keuntungan finansial, akun ini juga menerima iklan yang bisa dicantumkan baik dalam postingan maupun iklan berupa baris-baris kalimat dalam caption.

Mayoritas konten memang bermuatan romansa, motivasi jodoh 
sejalan dengan wajah yang ditampilkan akun ini kepada publik. Muatan religi masih begitu dominan di akun ini. Sekali lagi, ini menunjukkan bagaimana media siber memberi fasilitas untuk berdakwah dengan cara yang unik dan berbeda untuk menarik perhatian masyarakat.

\section{Akun siraman.rohani}

Akun ini adalah akun religi umat kristiani. Dengan jumlah pengikut sebanyak 189 ribu akun serta postingan sebanyak 3037 postingan, respons pengikut dalam akun ini bisa dikatakan cukup aktif. Rata-rata komentar adalah lima puluh komentar di setiap postingan dengan isi komentar beragam, seperti mengamini atau menyetujui konten, beriklan, atau membagikan pengalaman kepada pengikut lainnya.

Semenjak akun ini adalah akun religi milik umat Kristiani, kontenkonten di dalamnya pun berisi pengajaran kehidupan yang didapat dari Alkitab serta ajaran untuk berbuat baik dan beriman kepada Tuhan. Kontenkonten yang berkaitan dengan pengajaran dikemas dalam bentuk katakata bijak yang disusun dengan bahasa yang indah dan nyaman dibaca, motivasi kehidupan, serta puisi-puisi religi. Selain itu, postingan tidak hanya berisi kata-kata, namun juga dibalut dengan ilustrasi-ilustrasi gambar yang makin membuat postingan itu menarik secara visual.

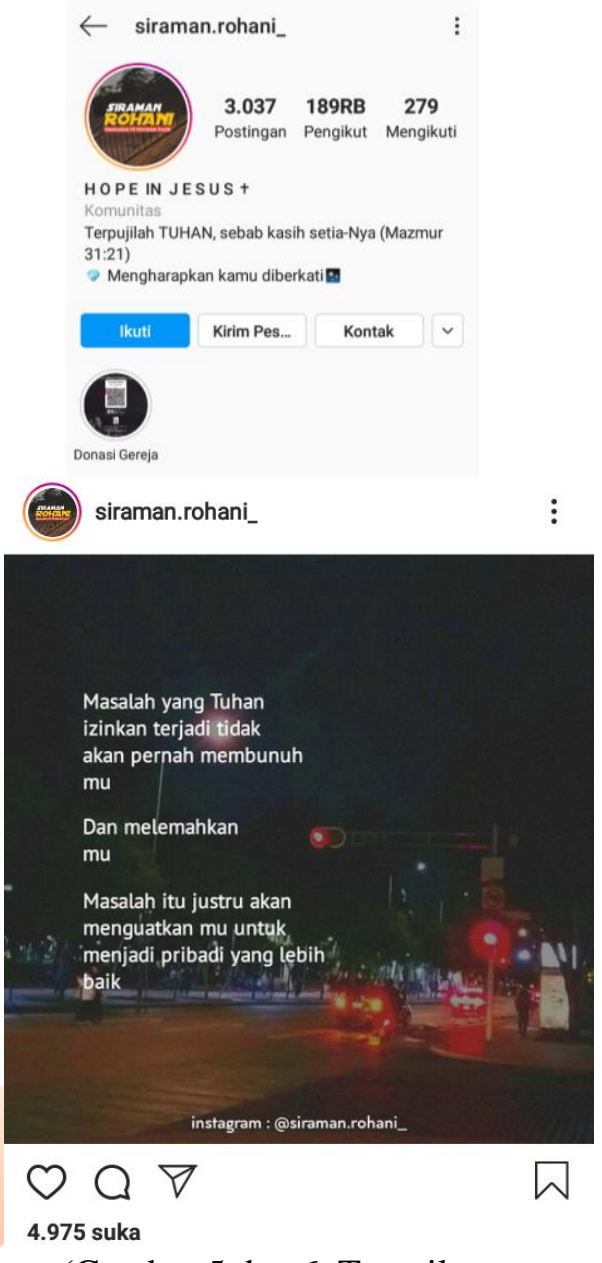

(Gambar 5 dan 6. Tampilan Instagram akun siraman.rohani_)

Terdapat juga postingan iklan baik berupa paid promote ataupun iklan dalam bentuk postingan. Hal semacam ini memang tidak bisa dilepaskan dari media sosial seiring maraknya budaya belanja online yang berkembang di masyarakat. Memasang iklan di media sosial tentu saja membantu dan hal ini juga membantu pemilik akun yang mengiklankan untuk mendapatkan keuntungan yang bisa mendukung keberlangsungan akun tersebut.

Sedikit berbeda dari akun-akun yang sudah dibahas sebelumnya, akun 
siraman.rohani_ juga memiliki kanal YouTube sendiri. Di dalam kanal YouTube-nya, akun ini memiliki sekitar 4.74 ribu pelanggan dan berisi videovideo renungan, penjelasan mengenai sebuah artikel yang membahas sejarahsejarah yang terjadi di umat Kristiani juga beberapa pembacaan puisi religi. Hal ini menunjukkan bagaimana media siber bisa menghubungkan dua media berbeda namun dengan pengelolaan serupa. Dengan hal ini, pengikut bisa menonton, membaca, ataupun melihat konten-konten religi tersebut, kapan pun, di mana pun, dan tidak harus menunggu lama. Selagi mereka terhubung dengan internet, segala hal bisa dilakukan dengan mudah.

\section{Akun filsafat_hindu}

Akun yang bernapaskan konten religi umat Hindu ini memiliki pengikut yang cukup banyak, yaitu sebanyak 262 ribu pengikut. Sedikit berbeda dengan akun lainnya yang mayoritas berisi puisi-puisi pendek, kata-kata bijak, dan video grafis, sastra yang terdapat dalam akun ini lebih dimainkan dalam caption yang dibubuhkan di setiap postingan. Hal-hal yang diposting sendiri adalah foto-foto kegiatan keagamaan umat Hindu. Caption yang dibubuhkan di setiap postingan bisa dibilang cukup panjang dan merupakan kutipan dari sastra kuno maupun dari kitab-kitab. Selain itu, terdapat juga postingan seputar filsafat kehidupan, ensiklopedi seputar agama Hindu. Akun ini juga dimanfaatkan untuk promosi bukubuku, serta promosi produk-produk dagang seperti aksesoris keagamaan semacam gelang, dan lain-lain. Dua hal yang sangat dominan dari akun ini adalah konten fotografi yang diunggah serta permainan caption yang banyak menggunakan kutipan kata-kata indah dari sastra kuno maupun kitab. Yang menarik dalam akun ini adalah captioncaption yang dibubuhkan. Selain katakata indah yang merupakan kutipan dari sastra kuno ataupun kitab-kitab, selalu ditambahkan dengan tambahan informasi yang menyertainya. Sehingga tak sedikit postingan yang menggunakan caption yang cukup panjang.

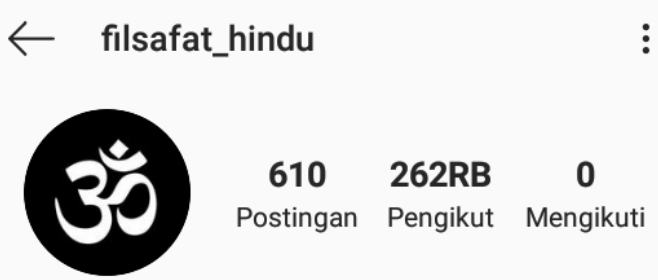

Sanātana Dharma

Blogger

न हि ज्ञानेन सदृशं पवित्रमिह विद्यते

Tidak ada yang semurni jñāna, agama tak lebih balutan jubah ego

Lihat Terjemahan

bit.ly/390YISN
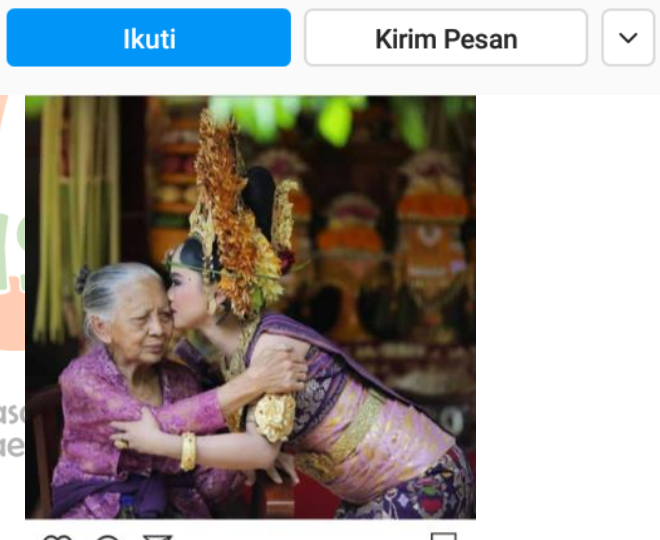

$\circ \subset \nabla$

15.746 suka

filsafat hindu "Oleh sebab itu, baktilah pada orang tua bahkan layani mereka dengan ketulusan hati. Jika diminta atau jika tidak diminta sekalipun, tawarkan terlebih dahulu keinginan untuk mengantar kemanapun beliau hendak pergi, jika berkenan antarlah beliau dengan hati yang tulus."

-Lontar Sarasamuscaya (248)

(Gambar 7 dan 8. Tampilan laman Instagram akun filsafat_hindu) 
Bisa dikatakan, akun ini tidak hanya membahas seputar agama Hindu saja, namun juga mengenai falsafah kehidupan. Seperti ajaran untuk selalu berbuat baik, rendah hati, dan lain-lain. Hal itu menyebabkan interaksi antarpengikut di kolom komentar sangat aktif. Tidak hanya soal menyetujui atau mengamini, para pengikutnya bahkan juga ikut berdiskusi di kolom komentar mengenai berbagai permasalahan yang kadang sesuai dengan isi postingan namun kadang sedikit keluar dari topik. Diskusi-diskusi semacam inilah yang jarang ditemukan di akun-akun yang lain. topik-topik yang diangkat di tiap postingan memang menarik untuk mengundang diskusi.

\section{Akun buddha.dhamma.kehidupan}

Seperti nama pengguna yang digunakan dalam akun ini, akun ini adalah akun yang berisi pengajaran kehidupan serta kepercayaankepercayaan agama Buddha. Jika dibandingkan dengan akun lain, akun ini memang akun yang memiliki jumlah pengikut paling sedikit yaitu 29 ribu pengikut dengan total postingan sejumlah 1312 postingan. Dari segi konten pun, bisa dikatakan bahwa akun ini banyak mengunggah gambargambar yang berisi tulisan-tulisan pengajaran kehidupan dari Buddha. Cara pengemasan kontennya pun bisa dibilang kurang menarik. Hal ini bisa terlihat dari desain dan konsep setiap postingan yang tidak membentuk suatu konsep tertentu dalam tata letak atau biasa disebut feed. Namun, jika ditinjau melalui tujuan dari akun ini sendiri yaitu memberikan pengajaran kehidupan untuk selalu berbuat baik, dirasanya akun ini sudah berhasil mencapai hal tersebut meskipun respons dari pengikutnya masih termasuk sedikit. Berbeda juga dangan akun yang lain, tidak ada konten berisi iklan atau hal-hal serupa yang bertujuan untuk mendapatakan keuntungan finansial.

\section{Kontribusi Media Siber terhadap Sastra Religi di Instagram}

Seperti yang sudah dijelaskan secara panjang lebar di atas, cyber sastra adalah aktivitas sastra yang memanfaatkan fasilitas internet dan komputer. Salah satu fungsi sastra sebagai media pengajaran pada pembaca memang cocok dengan sastra religi. Sastra religi adalah sastra yang bernuansa religi yang mengandung ajaran-ajaran baik untuk taat dan patuh kepada Tuhan. Kehadiran internet memang memberikan napas baru dalam kehidupan manusia, terlepas dari berbagai dampak yang menyertainya, internet adalah hal yang tidak bisa dipisahkan lagi dari kehidupan dewasa ini. Internet ataupun media siber banyak dimanfaatkan dalam berbagai bidang baik itu pendidikan, ekonomi, sosial, bahkan juga di bidang sastra. Internet sebagai salah satu penopang berkembangnya media siber pun memberikan banyak kontribusi untuk perkembangan sastra religi utamanya keberadaan sastra religi di media sosial. Kontribusi tersebut di antaranya:

\section{Menjadikan sastra religi sebagai salah satu genre sastra yang bisa dinikmati semua kalangan masyarakat}

Sastra religi adalah salah satu genre sastra yang sudah lekat di benak masyarakat sejak lama. Dewasa ini, sastra religi muncul dalam berbagai media siber yang populer di tengah masyarakat seperti Instagram. 
Instagram memang bukan aplikasi yang dibuat khusus untuk membagikan karya sastra seperti novel, cerpen, atau puisi. Namun manusia yang dianugerahi akal dan pikiran oleh sang pencipta dengan kreativitasnya bisa menjadikan Instagram sebagai salah satu aplikasi yang bisa digunakan sebagai wadah sastra. Seperti menurut Septriani (2016), media cyber membuka alternatif penyajian karya sastra, misalnya tayangan puisi yang diiringi musik, suara, dan latar grafis yang indah. Hal seperti itu akan membuat karya menjadi lebih menarik dan menghadirkan ruang terbuka bagi siapapun untuk menyalurkan kreativitasnya. Seperti halnya novel dan cerpen yang bisa diekranisasi menjadi film, dengan adanya teknologi memungkinkan munculnya bentukbentuk kembangan dari sastra. Di media sosial Instagram, marak adanya video grafis yang diiringi oleh suara pembacaan puisi, musikalisasi puisi, maupun lainnya. Selain itu ada juga konten-konten puisi pendek yang didesain sedemikian rupa dengan gambar-gambar latar belakang yang bermacam-macam. Hal ini cukup menunjukkan bagaimana di era digital ini sebuah bentuk karya sastra konvensional seperti puisi bisa dikembangkan dalam bentuk baru baik itu dalam bentuk video grafis maupun desain grafis. Tanpa adanya teknologi yang mendukung tentu saja hal itu tidak akan bisa terealisasikan. Hal ini juga menjadi nilai tambah tersendiri dari adanya sastra religi di media siber.

Dengan berkembangnya tampilan baru seperti video grafis untuk membalut konten bernuansa religi, membuat jangkauan penikmat menjadi lebih luas lagi. Sastra religi tidak lagi lekat dengan pembaca dewasa, namun dengan bentuk baru ini sastra religi dapat menjangkau generasi-generasi muda untuk bisa ikut menikmati konten-konten tersebut. Munculnya berbagai aplikasi maupun situs menjadikan penyebaran sastra di tengah-tengah masyarakat menjadi tidak memiliki batasan. Karya sastra bisa dengan mudah sampai ke tangan pembaca tanpa perantara.

Sisi positif lain yang muncul dengan adanya media siber adalah memungkinkan banyaknya penikmat sastra yang dapat menjangkau sebuah karya sastra. Dengan konten-konten sastra religi di Instagram, seorang penikmat sastra tidak perlu lagi datang jauh-jauh ke toko buku untuk mendapatkan karya sastra yang ia mau. Septriani (2016) mengujarkan dalam sastra cyber, sebuah karya dapat menyebar ke seluruh penjuru dunia hanya dalam hitungan detik dan sastra cyber menjadi ajang publikasi yang murah dan mudah. Penikmat sastra hanya perlu tersambung ke jaringan internet, seorang pengguna media sosial bisa mengakses apapun yang hendak ia akses. Hal ini tidak hanya menguntungkan bagi penikmat sastra saja, bagi penggagas dan penulis hal ini juga memberikan banyak manfaat. Seperti yang diujarkan Supriani (2018), fungsional sastra online mendorong berkembangnya sastra Indonesia menjadi ruang ekspresi imajinatif untuk siapapun. Dengan tidak adanya batasan, semua orang bisa bebas membuat konten yang ia mau. Semua orang bisa bebas membuat akun-akun religi berbalut sastra dengan mudah. Hal itu akan dengan mudah pula diakses oleh para pembaca. Hal ini bisa menjadikan keanekaragaman dalam khazanah sastra juga proses regenerasi terus berlangsung agar sastra Indonesia 
khususnya sastra religi tetap bertahan dan tidak termakan zaman.

\section{Menyediakan tempat berdakwah tanpa batasan waktu dan tempat}

Adanya media cyber, menjadikan berkembangnya berbagai hal baru dan berbagai terobosan yang membantu kehidupan manusia. Sastra religi lekat dengan tujuan dakwah. Dengan adanya akun-akun Instagram yang memposting konten-konten bermuatan religi menjadi salah satu jalan dalam melakukan dakwah. Dalam akun islami contohnya, dengan konten-konten puisi ketuhanan, ajakan berbuat baik, kutipan ayat Alquran maupun hadis adalah cara lain dalam berdakwah dan terbukti cara itu pula yang menarik minat pengguna untuk mengikuti akun tersebut. Atau dalam akun siraman.rohani_ sebagai misal, memposting puisi-puisi dan katakata indah untuk mengajarkan keimanan kepada Tuhan. Hal tersebut juga berlaku di akun-akun yang lain.

\section{Menjadi tempat mencari keuntungan finansial}

Selain itu, berkembangnya sastra siber menjadikan banyak orang bisa menjangkaunya. Hal ini juga dimanfaatkan oleh akun-akun yang telah disebutkan sebagai tempat untuk mencari keuntungan. Meskipun tidak sepenuhnya bisa disebut sebagai hal positif, setidaknya ini bisa menjadi salah satu cara agar akun-akun bersangkutan terus bertahan dan tetap memproduksi karya-karya sastranya dengan dukungan finansial dari para pengikut dengan iklan-iklan yang ditampilkan dalam akun.

\section{Dampak Negatif Media Siber Terhadap Sastra Religi di Media Instagram}

Di samping hal-hal positif yang sebelumnya telah disebutkan hadirnya sastra siber di tengah khazanah dunia sastra Indonesia juga memberikan dampak negatif di sisi yang lainnya. Tidak adanya batasan dan siapa saja bisa membuat karya sastra sendiri. Hal ini membuat resiko menurunnya kualitas dari karya sastra yang beredar di masyarakat menjadi semakin besar. Tidak adanya kurator, yang mengontrol sebuah karya yang beredar di masyarakat membuat beragamnya karya sastra yang beredar di masyarakat tidak semuanya bagus dan memberikan dampak positif bagi pembacanya. Dalam kaitannya dengan sastra religi sendiri, pembicaraan yang berkaitan dengan religi memang cukup sensitif. Jika bukan orang yang betul-betul paham dengan ilmu yang melatarbelakangi suatu hal bisa memberikan kesalahpahaman di tengah pembaca. Topik-topik religi yang biasanya dibawakan oleh tokoh agama yang memang sudah memiliki latar belakang ilmu yang mumpuni ini bisa dibawakan oleh siapa saja. Dengan adanya sastra siber, utamanya yang ada di media sosial, seorang pengikut sangat sulit untuk bisa benar-benar mengetahui siapa yang ada di balik sebuah akun sastra religi yang mereka ikuti. Pengikut atau di sini bisa disebut pembaca tidak tahu apakah penulis memiliki pengetahuan yang cukup dalam membuat sebuah konten dan apakah konten itu bisa dipercaya atau tidak. Pembaca juga tidak pernah benar-benar tahu tujuan dan ideologi seperti apa yang dibawa oleh penulis semenjak komunikasi mereka dibatasi oleh representasi yang dihadirkan penulis di media siber.

Dengan adanya media siber seperti ini, risiko terjadinya plagiarisme juga 
semakin besar. Utamanya dengan hadirnya puisi-puisi pendek, video grafis, maupun desain grafis yang tersebar luas tanpa terkendali. Seseorang bisa dengan mudah mengutip atau bahkan mengunggah kembali karya orang lain tanpa izin. Tidak jarang ditemui satu konten puisi pendek yang tersebar ke berbagai akun tanpa menandai atau menyebutkan siapa pembuat konten bersangkutan. Hal ini menuntut pembuat karya, konten, atau penulis harus pandai dalam melindungi karyanya. Entah itu dengan menambahkan watermark pada konten yang ia buat, atau yang lainnya. Dengan begitu, meskipun sebuah konten tersebar dan diunggah ulang ke berbagai akun, seorang pembaca dapat tetap mengidentifikasi siapa pembuat konten tersebut.

Komersialisasi yang dilakukan penulis membuat sastra siber dipandang sebelah mata. Di samping memudahkan seorang penulis untuk mempromosikan karyanya seperti buku, antologi, atau novel yang telah diterbitkan, komersialisasi yang dilakukan membuat beberapa pembaca yang tidak begitu simpati dengan kapitalisme tidak menyukai komersialisasi yang dilakukan. Hal ini berpengaruh pada persepsi publik terhadap sastra religi yang berada di media-media Jusosial seperti Instagram.

Namun terlepas dari dampak negatif yang dibawa, tidak dapat dipungkiri juga jika kehadiran sastra siber memang menambah heterogenitas dalam khazanah sastra Indonesia. Hadirnya media siber dalam dunia sastra juga membuat sastra religi makin dekat di masyarakat. Hal ini membuat makin menipisnya pandangan hierarki genre sastra. Karena dengan adanya media siber, sebuah karya sastra bernuansa agamis bisa dibaca oleh siapa pun, dan setiap orang bisa membuat karya sastra sesuai dengan ideologi yang dipercaya tanpa perlu khawatir karyanya tidak akan diterima oleh kurator. Karena sejatinya dalam sastra siber, yang menjadi kurator adalah pembaca itu sendiri.

\section{PENUTUP}

\section{Simpulan}

Instagram ada salah satu media sosial dengan jumlah pengguna fantastis yang kemudian digunakan oleh banyak orang untuk meraih tujuannya masing-masing. Sastra religi adalah salah satu genre sastra yang kemudian ikut masuk ke dalam arus digital dan memanfaatkan media siber untuk berbagai macam hal. Kontenkonten yang terdapat pada akun-akun sastra religi di media sosial ada beraneka ragam. Tidak keluar dari jalurnya sebagai tujuan sebagai salah satu alat untuk berdakwah dan menyebarkan kebaikan. Konten-konten yang berupa video, gambar, dan tulisan sama-sama bertujuan untuk memberikan nilai dan pelajaran kehidupan untuk pengikut-pengikutnya. Karena media penyebarannya adalah media siber, maka keberadaan sastra religi pun sedikit berbeda dengan sastra arkenvensional pada umumnya.

dan Hal erni kemudian mengarah pada kontribusi yang diberikan media siber kepada sastra religi. Dengan media siber, kemudahan untuk menyebarkan karya menjadi semakin terbuka. Semua orang bisa ikut serta dalam menyebarkan dan mengunggah karyakaryanya. Kontribusi yang dibawa media siber kepada sastra religi adalah dengan menjadikan sastra religi sebagai sebuah sastra yang bisa dijangkau oleh 
banyak pembaca dan penikmat dari berbagai usia. Sastra religi di media sosial Instagram dikemas dengan sedemikian rupa menjadi lebih menarik sehingga banyak pembaca-pembaca mudah yang kemudian ikut mengikuti dan menikmatinya. Hal itu membuat peluang bagi kreator konten sastra religi di Instagram untuk menyebarkan tujuan dakwahnya. Dakwah tidak lagi lekat dengan sesuatu yang kaku yang harus dilakukan dalam kajian-kajian. Namun dengan sastra religi di media siber, dakwah dapat dilakukan dengan berbagai macam cara, waktu, dan tempat. Hal terakhir yang tak luput dari hadirnya media siber di tengah khazanah sastra religi di Indonesia adalah dengan menjadikan akun-akun di Instagram menjadi tempat mencari keuntungan finansial. Bersama banyaknya jumlah pengikut yang ada pada sebuah akun, jumlah iklan yang masuk semakin banyak dan makin berlimpah pula keuntungan finansial yang didapatkan. Pada akhirnya, media siber menjadi sebuah wadah bagi sastra religi untuk terus ada dan berkembang di tengah masyarakat. Menghadirkan teladan-teladan lewat postingannya dan menjadikan sastra religi sebagai sebuah sastra yang dapat dinikmati semua orang.

\section{DAFTAR PUSTAKA}

Buddha.dhamma.kehidupan.

Desember).

https://www.instagram.com/buddha. dhamma.kehidupan/.

Cinthya, N., \& Wati, R. (2020). Fenomena sastra cyber: trend baru sastra islami dalam masyarakat modern di indonesia. Jurnal Edukasi Khatulistiwa Pembelajaran Bahasa dan Sastra Indonesia, 1-8.
Endraswara, S. (2013). Metodologi penelitian sastra, epistemologi, model teori dan aplikasi. Yogyakarta: CAPS.

Filsafat_hindu. (2020, Desember). from https://www.instagram.com/filsafat_ hindu/.

Kisahcintamuslimah. (2020, Desember). from https://www.instagram.com/kisahcin tamuslimah/.

Ong, W. J. (2013). Kelisanan dan keaksaraan. Yogyakarta: Gading.

Pradopo, R. D. (2018). Beberapa teori sastra, metode kritik, dan penerapannya. Yogyakarta: Pustaka Pelajar.

Ratna, N. K. (2009). Stilistika kajian puitika bahasa, sastra, dan budaya. Yogyakarta: Pustaka Pelajar.

Remaja.islami. (2020, Desember). from https://www.instagram.com/remaja.i slami/.

Septriani, H. (2016). Fenomena sastra cyber: kemajuan atau kemunduran? Seminar Nasional Sosiologi Sastra di Fakultas Ilmu Pengetahuan Budaya, Universitas Indonesia, (pp. 1-15). Depok.

Siraman.rohani_. (2020, Desember). from

https://www.instagram.com/siraman. rohani_/

Jurnal llmichujarwa. (2019). Metode dan Pendidikan barksadisastra teori sosiologi sastra. (2020, Yogyakarta: Pustaka Pelajar.

from Supriani, R. (2018). Kajian sosiologi sastra pada fenomena sastra online. Seminar Nasional Bahasa dan Sastra Indonesia I (pp. 65-70). Medan: Universitas Negeri Medan.

Yulhasni. (2018). Cyber sastra: perlawanan terhadap hegemoni dalam sastra indonesia. Jurnal Komposisi, 106-109. 